RAD Conference Proceedings, vol. 3, pp. 166-168, 2018

ISSN 2466-4626 (online) | DOI: 10.21175/RadProc.2018.36

www.rad-proceedings.org

\title{
ENSURING PROTECTION AND SAFETY IN THE HANDLING OF A DECEASED PERSON THAT IS KNOWN TO CONTAIN AN UNSEALED RADIOACTIVE SOURCE AS A RESULT OF MEDICAL TREATMENT - HEALTH AUTHORITY CASE STUDY
}

\author{
Fulger Ciupagea1, Gabriela Rosca Fartat ${ }^{*}$, Marina Anghene1, \\ Nuta Niculaie', Anca Zamfirescu², Cristina Petroiu², Costin Ghioca 3 \\ ${ }^{1}$ Public Health Directorate-Ionizing Radiation Laboratory, Bucharest, Romania \\ ${ }^{2}$ Oncological Institute, Bucharest, Romania \\ 3AC RAD Medical Consult \& Service SRL, Bucharest, Romania
}

\begin{abstract}
Radioactive sources used for therapy can cause very serious exposures if they are mislaid or misused. The aim of this paper is to present the measures taken in order to ensure the radiation protection in the handling of a deceased person containing I-131. The prominent pathways of exposure for occupational exposed personnel, medical exposure (family, friends) and public exposure (third person e.q. (the mortuary car driver, priest) were assessed. According to these specific conditions, the time after which the body can be taken over by the family was calculated and the doses in the handling of the deceased person, embalming, transport and burial ceremony were evaluated for each category of people. Also, the compliance with national legislation and European recommendations is discussed.
\end{abstract}

Key words: Cancer thyroid, deceased person containing I-131, dose constraint, nuclear medicine, planned exposure, radionuclide therapy patient

\section{INTRODUCTION}

Since the discovery of radioactivity, radioactive materials have been used for diagnosis and treatment.

In order to ensure the radiation protection for the occupational exposed workers, public and environment, the radiopharmaceutical therapy is considered a specifically planned exposure situation, for each individual patient [1].

The source related principles of justification and optimization are applied to this medical planned exposure situation. The treatment of thyroid cancer with I-131 is considered justified according to the first and the second level of justification recommended by ICRP 105 [2].

The administration of the radiotherapy procedure to an individual patient shall be decided by the practitioner taking into consideration the specific patient's condition (the third level of justification for medical exposure) [2].

There is a possibility that the patient may die before the radioactive material has decayed away, either from the disease being treated, or from an unrelated cause.

In this rare event, the licensee shall ensure the radiation protection and safety during the handling of the deceased person.

\footnotetext{
gabriela.fartat@yahoo.com
}

The aim of this paper is to present the actions taken by the Romanian Health Authority in consultation with the experts in radiation protection in order to implement the existing legal provisions related to the dose constraint as a tool for the optimization of the protection for occupational exposed workers and for the public.

\section{LEGAL FRAMEWORK}

Following international recommendations ${ }^{[3]}$ and the European Directives [4], the Romanian legislation requires advice of a qualified expert and special authorization for necropsy, embalming, incineration, if a patient dies shortly after the administration of I-131 for therapeutic purposes [5], [6].

\section{THE CASE}

Under the responsibility of the nuclear medicine physician, according to the protocols established in the Isotopic Radiotherapy Department a capsule containing I-131 was administered to a patient for the ablation treatment of thyroid neoplasm. From the medical records and clinical observations the imminent death of the patient could not be predicted.

The capsule activity was measured prior to administration with an adequate and calibrated dose 
calibrator. The measured activity of the administrated capsule was $5.44 \mathrm{GBq}$.

\section{RADIOLOGICAL RISK ASSESSMENT AND RADIATION PROTECTION ACTIONS}

\subsection{Immediate actions}

The immediate actions taken by the licensee were according to the local procedures, as follows:

It has been established, in consultation with a qualified radiation protection expert, that the deceased patient cannot be taken over by the family for burial. This can be allowed only after the necessary time to ensure the physical disintegration of the radiopharmaceutical to an activity leading to the dose constraints regulated for the public;

The body was stored in the Department of Pathological Anatomy, taking measures to ensure the radiation protection of the workers in this service;

The body's storage area was classified as a controlled area and appropriate local rules were established;

Measurements of the ambient equivalent dose rate were performed and additional shielding was added to the refrigerator door. The results are shown in Table 1.

Table 1. The maximum instantaneous value of the ambient dose rate equivalent $(\mu \mathrm{Sv} / \mathrm{h})$

\begin{tabular}{|l|c|}
\hline \multicolumn{1}{|c|}{ Measuring point } & $\begin{array}{c}\text { Value } \\
(\mu \mathrm{Sv} / \mathrm{h})\end{array}$ \\
\hline \multicolumn{2}{|c|}{ Without supplementary shielding } \\
\hline 1m distance from the body & 287 \\
\hline $\begin{array}{l}\text { 1m distance from the unshielded } \\
\text { refrigerator door }\end{array}$ & 0.45 \\
\hline $\begin{array}{l}\text { o.3 m from the unshielded } \\
\text { refrigerator door }\end{array}$ & 45 \\
\hline Work place & 5 \\
\hline $\begin{array}{l}\text { The refrigerator door shielded with a } \\
\text { supplementary mobile lead shield }\end{array}$ & 0.25 \\
\hline $\begin{array}{l}\text { 1m distance from the refrigerator } \\
\text { door }\end{array}$ & 9 \\
\hline O.3 m from the refrigerator door & 1.5 \\
\hline Work place & \\
\hline
\end{tabular}

The stay time of the personnel working in the premises was reduced to the time required to perform the job responsibilities in the area;

The patient's family was contacted to be informed that the deceased patient can be prepared, transported and buried after a reasonable time, agreed after the qualified expert's assessment of the period of time necessary to ensure the radiation protection of the members of the public.

\subsection{Effective dose calculation}

We considered the external irradiation as being the predominant pathway of exposure for people in the vicinity of the deceased patient. The internal contamination through transfer by direct contact with the skin of the deceased patient shall be avoided following special instructions. The personnel involved in handling of the deceased patient for embalming and in the transport to the place of the funeral service, as well as the people attending the funerals were considered to be members of the public for which we applied the dose constraint value of $1 \mathrm{mSv}$.

The deceased patient represents a point radioactive source (for the calculation of external dose rates). The use of a linear or dispersed radioactive source in a volume will lead to lower doses. Patients typically have the activity distributed throughout the body, attenuating some of the radiation. For this reason, the point source method is very conservative.

Taking into account that within the first several hours post administration, no activity is biologically eliminated from the body, and the exponential components representing the metabolic comportment could be neglected, we considered the effective half-life equal to I-131 physical half-life.

For the dose calculation we used adapted equations from Zanzonico [7], published in NCRP Report No.155 [8]:

$$
\begin{aligned}
& \mathrm{A}(\mathrm{t})=\mathrm{A}(0) \sum_{\mathrm{i}=1}^{\mathrm{n}} F_{i} e^{-\frac{0.693 t}{T \frac{2}{z}}} \\
& D(0 \rightarrow t)=\frac{34.6 x O F x A(0) x T_{\frac{1}{2}} x \Gamma\left(1-e^{-\frac{0.693 t}{T_{2}}}\right)}{r^{2}}
\end{aligned}
$$

were:

$\mathrm{A}(\mathrm{O})=$ total body administrated activity

$\mathrm{A}(\mathrm{t})=$ total body activity $(\mathrm{Bq})$ at time $\mathrm{t}$ post administration (days).

$\mathrm{F}_{\mathrm{i}}=$ zero-time intercept of exponential component of the total activity expressed as a fraction of the administrated activity, such that $\sum_{i=1}^{n} F i=1$.

$\Gamma=$ specific activity for $\mathrm{I}-131\left(\Gamma=2.2 \mathrm{R}-\mathrm{cm}^{2} / \mathrm{mCi}-\mathrm{h}\right)$

$\mathrm{D}(\mathrm{O} \rightarrow \mathrm{t})=$ dose during the exposure time

$\mathrm{OF}=$ occupancy factor equal to 1

$\mathrm{r}=$ the distance from the body

$\mathrm{T}_{1 / 2}=$ physical half time for I-131 equal to 8.04 days

$34.6=$ factor for conversion of time in days to time in hours multiplied by 1.44 (1.44=1/(0.693).

\subsection{Results}

Table 2. The doses estimation for the persons participating to the embalming, transport and burial of the deceased person containing I-131

\begin{tabular}{|l|c|c|c|}
\hline Exposed person & $\begin{array}{c}\text { Stationary } \\
\text { time (h) }\end{array}$ & $\begin{array}{c}\text { Distance } \\
(\mathrm{m})\end{array}$ & $\begin{array}{l}\text { Estimated } \\
\text { dose (mSv) }\end{array}$ \\
\hline $\begin{array}{l}\text { Embalming } \\
\text { personnel } \\
\begin{array}{l}\text { Mortuary car } \\
\text { driver }\end{array}\end{array}$ & 2 & 0.3 & 0.99 \\
$\begin{array}{l}\text { Participant to } \\
\text { burial ceremony }\end{array}$ & 10 & 1 & $0.13^{-}$ \\
\hline
\end{tabular}


The results obtained based on the above presented calculation model change are presented in Figure 1.

The estimated doses for the persons in relation with the distance and the stationary time near the body of the dead patient after 23 days from the date of death are shown in Table 2.

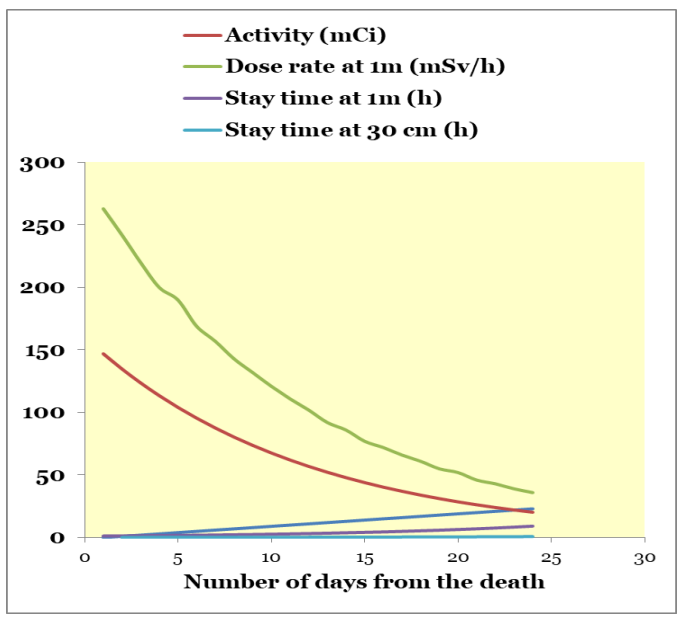

Figure 1. Dependence on time of the activity, dose rate and stay time

\section{CONCLUSION}

The autopsy is prohibited 102 days from the date of death, the date when the activity reaches the value of $1 \mathrm{MBq}$ provided by the regulation in force.

The embalming and preparation of the deceased patient can be done 23 days after the date of death. Embalming can be done by the injection method, the risk of contamination being lower.

The transport of the deceased patient can be done 23 days after the date of death. During the entire transport from the Bucharest Oncological Institute to the location chosen for the funeral ceremony, the coffin will be closed. The use of a transport route that ensures a minimum travel time, avoiding crowded traffic as much as possible is recommended.

In order to keep members of the public at the dose constraints imposed by the radiation protection regulations in force, burial can be done 23 days after the date of death.

The risk of exposure through contamination is minimal and can be completely eliminated by the recommendation to avoid direct contact with the deceased patient.

It was recommended that the coffin should be closed during the funeral ceremony.

Also, to reduce the risk of external exposure, it was recommended that people participating in the funeral ceremony (family, relatives, friends, funeral ceremony officers) shall be away from the deceased patient as far as possible.

The stationary time at a distance of $1 \mathrm{~m}$ from the deceased patient should not be longer than 10 hours.
The stationary time at a distance of $30 \mathrm{~cm}$ must not be longer than two hours.

Acknowledgements: The authors would like to thank to qualified radiation protection experts for their contribution in revising this paper and for the support offered by AC RAD Medical Consult \& Service $S R L$ to participate in the RAD 2018 Conference.

\section{REFERENCES}

1. The 2007 Recommendations of the International Commission on Radiological Protection, ICRP Publication 103, ICRP, Ottawa, Canada, 2007. Retrieved from: http://www.icrp.org/docs/ICRP_Publi cation 103-Annals of the ICRP $37(2-4)$ Free extract.pdf; Retrieved on: Jun. 14, 2018

2. Radiological Protection in Medicine, ICRP Publication 105, ICRP, Ottawa, Canada, 2007.

DOI: 10.1016/j.icrp.2008.08.001 PMid: 18762065

3. Radiation Protection and Safety of Radiation Sources: International Basic Safety Standards, General Safety Requirements Part 3, IAEA, Vienna, Austria, 2014, p. 24.

Retrieved from: https://wwwpub.iaea.org/MTCD/publications/PDF/Pub1578 web57265295.pdf; Retrieved on: Jun. 14, 2018

4. The Council of the European Union. (Jun. 30, 1997). Council Directive 97/43/Euratom on health protection of individuals against the dangers of ionizing radiation in relation to medical exposure, and repealing Directive 84/466/Euratom.

Retrieved from: https://eur-lex.europa.eu/legalcontent/en/TXT/?uri=CELEX\%3A31997L0043; Retrieved on: Jun. 30, 2018

5. Ministry of Health and National Commission for Nuclear Control Activities. (Jun. 25, 2002). No. 285/79/2002 Norms on Radiation Protection in Medical Exposures.

Retrieved from: http://www.cncan.ro/assets/Legislatie /Norms/Norms-on-radiation-protection-ofindividuals-in-NSR-04.pdf

Retrieved on: Jun. 12, 2018

6. Comisia Nationalã Pentru Controlul Activitãtilor Nucleare. (Feb. 15, 2005). 358/2004 ordin privind aprobarea normelor de securitate radiologicã pentru practica de medicinã nuclearã. (National Commission for the Control of Nuclear Activities. (Feb. 15, 2005). No. 358 Regulation on radiation safety in nuclear medicine.)

Retrieved from: http://www.dsclex.ro/legislatie/2005/f ebruarie2005/mo2005 139.htm;

Retrieved on: Jun. 30, 2018

7. P. B. Zanzonico, J.A. Siegel, J. St German, "A generalized algorithm for determining the time of release and duration of post release precautions radionuclide therapy," Health Phys., vol. 78, no. 6, pp. 648 - 659, Jun. 2000.

DOI: 10.1097/00004032-200006000-00007 PMid: 10832924

8. Management Radionuclide Therapy Patient, NCRP Report No. 155, NCRP, Bethesda (MD), USA, 2006. Retrieved from: http://www.ncrppublications.org/Repo rts/155;

Retrieved on: Jun. 30, 2018 